\title{
Pemberdayaan Kelompok Istri Tani Ternak melalui Pembuatan Produk Olahan Susu di Kelurahan Wates, Kota Semarang, Jawa Tengah
}

\section{The Empowerment of Livestock Farmer's Wife Group through Making Dairy Products in Wates Village, Semarang City, Central Java Province}

\author{
Lucia Hermawati Rahayu ${ }^{1}$, Ronny Windu Sudrajat ${ }^{2}$, Sri Sutanti ${ }^{3}$ \\ Politeknik Katolik Mangunwijaya Semarang, Kota Semarang \\ 1lucia.hermawati97@gmail.com,
}

Riwayat Artikel: Dikirim 1 Oktober 2018; Diterima 11 November 2018; Diterbitkan 30 November 2018

\begin{abstract}
Abstrak
Susu merupakan bahan makanan dengan kandungan gizi yang lengkap, tetapi mudah mengalami kerusakan. Pengolahan susu menjadi produk olahan susu harus dilakukan guna menanggulangi kerusakan susu segar dan memberi nilai tambah susu. Namun, masih banyak petani ternak yang belum mengolah susu yang tidak habis terjual karena keterbatasan pengetahuan dan keterampilan tentang pengolahan susu termasuk Kelompok Tani Ternak (KT'T) di Kelurahan Wates, Semarang. Padahal, keterampilan membuat produk olahan susu, seperti kerupuk dan stik susu, dapat dikembangkan untuk meningkatkan pendapatan masyarakat. Mitra kegiatan PKM ini adalah kelompok istri peternak sapi KTT Air Bening I dan KTT Air Bening II di Kelurahan Wates, Semarang. Kegiatan PKM yang dilakukan meliputi penyuluhan dan pelatihan pembuatan kerupuk dan stik susu, praktek pengemasan, pendampingan dalam mengembangkan dan mengolah susu segar menjadi produk olahan susu, serta monitoring kegiatan. Hasil dari program PKM adalah peningkatan keterampilan mitra dalam memproduksi makanan olahan susu yang dapat dikembangkan sebagai usaha kecil untuk sumber penghasilan tambahan.
\end{abstract}

Kata kunci: susu, kerupuk susu, stik susu

\begin{abstract}
Milk is an ingredient with a complete nutritional content, but is easily damaged. Processing milk into dairy product must be carried out in order to overcome the damage to fresh milk and gives added value to milk. However, there are still many livestock farmers who have not processed milk that has not been sold out due to limited knowledge and skills about milk processing including Kelompok. Tani Ternak. (KTT) who is a group of Livestock. Farmer in Wates Village, Semarang. In fact, the skills to make dairy products, such as crackers and milk stick which are common Indonesian snacks, can be developed to increase farmer's income. Partners of PKM activities are groups of wives of cattle farmers from the KTT Clear Water Summit I and the KTT Air Bening II in Wates Sub-district, Semarang. PKM activities include counseling and training in making crackers and milk sticks, packaging practices, mentoring about developing and processing fresh milk into dairy products, and monitoring other activities. The outcome of the PKM program is the improvement of partner skills in producing dairy product that can be developed by small businesses for additional sources of income.
\end{abstract}

Keywords: milk, milk crackers, milk sticks

\section{PENDAHULUAN}

Susu sapi murni merupakan bahan pangan bernilai tinggi karena hampir semua zat-zat makanan utama yang dibutuhkan manusia terdapat dalam susu dalam keadaan seimbang, mudah dicerna dan dapat diserap oleh tubuh. Susu banyak mengandung zat gizi, seperti protein, karbohidrat, lemak, vitamin dan beberapa mineral. Namun, susu juga dikenal sebagai bahan pangan yang mudah rusak. Pada suhu ruang, susu sapi murni hanya mampu bertahan dalam waktu kurang dari 24 jam (Saleh, 2004). 
Umumnya petani ternak sapi sudah mengetahui sifat susu yang tidak tahan lama. Meski demikian, masih banyak petani ternak yang tetap menjual produksi susunya dalam keadaan segar dan tidak mengolahnya apabila tidak habis terjual. Sisa susu biasanya dibuang begitu saja atau disimpan dalam refrigerator (bagi yang punya). Penyimpanan dalam refrigerator pun hanya mampu mempertahankan mutu susu tidak lebih dari 2 hari. Konsumen umumnya juga kurang suka membeli susu sapi segar yang sudah didinginkan dalam refrigerator.

Penjualan susu hasil ternak dalam bentuk susu segar dan tidak diolah ketika sisa, juga dilakukan oleh dua kelompok tani ternak (KT'T) yang berada di Kelurahan Wates tepatnya di RT 03/RW 01, Kecamatan Ngaliyan, Kota Semarang, Jawa Tengah. Kedua kelompok peternak itu adalah KTT 'Air Bening I' yang diketuai oleh Marsudi dan KT'T 'Air Bening II' yang diketuai oleh Kismanto. Produksi susu segar pada KTT 'Air Bening I' dengan 16 ekor sapi produktif (dari total 24 ekor) sekitar 80-90 lt/hari, sedangkan pada KTT 'Air Bening II' dengan 15 sapi produktif (total 22 ekor) antara 75-85 lt/hari. Susu sapi segar oleh kedua KT'T biasanya dijual kepada para tengkulak atau pengecer segera setelah diperah dengan harga relatif murah, yakni Rp 6.000,- per liter untuk pembelian lebih dari 5 liter atau Rp 7.000,- per liter bila pembelian kurang dari 5 liter. Hal ini dikarenakan sifat susu segar yang tidak tahan lama (mudah pecah/rusak) dan ketiadaan tempat penyimpan susu sapi segar (refrigerator). Penjualan susu segar dilakukan di depan rumah oleh istri peternak.

Susu sapi segar yang dihasilkan kedua KTT tidak selalu habis terjual. Ketidakmampuan melakukan diversifikasi produk pangan olahan susu menjadikan sisa susu segar biasanya hanya diberikan cuma-cuma kepada tetangga yang mau atau dicampurkan pada pakan sapi. Hal ini dikarenakan minimnya pengetahuan dan keterampilan tentang pengolahan susu dari para istri peternak dan keterbatasan modal usaha. Kondisi seperti ini menjadikan pendapatan harian para peternak menjadi berkurang.

Dari hasil wawancara dengan Marsudi dan Kismanto diketahui bahwa dari hasil penjualan susu segar setelah dikurangi biaya pembelian pakan (bekatul, ampas tahu, dedak kopi, ampas singkong, rumput), obat-obatan, dan biaya operasional, pendapatan rata-rata setiap peternak di kelompok ini hampir sama, yakni \pm Rp 80.000,- per hari atau sekitar Rp 2.400.000,- per bulan. Padahal sebagian besar istri peternak ini tidak bekerja atau berprofesi sebagai ibu rumah tangga yang hanya mengandalkan pendapatan dari suami, belum lagi keluarga para peternak rata-rata masih menanggung biaya hidup 2 orang anak yang masih sekolah/belum mandiri.

Selama ini para istri peternak kedua kelompok ini belum tahu dan menyadari jika susu sapi dapat diolah menjadi aneka produk pangan olahan susu yang lezat, bergizi, tahan cukup lama, dan bernilai jual lebih tinggi, seperti kerupuk susu, stik susu, dodol susu, dan permen susu.

Oleh karena itu, tim PKM Polteka Mangunwijaya tergerak untuk membina dan meningkatkan pengetahuan serta keterampilan para istri peternak kedua KTT tentang diversifikasi dan teknologi pengolahan susu sapi segar menjadi aneka produk makanan yang bergizi, tahan lama, dan bernilai jual tinggi, yakni kerupuk susu dan stik susu.

Penerapan program PKM ini diharapkan dapat mengoptimalkan pengolahan susu sapi segar (terutama yang tidak laku terjual) sebagai basis pengembangan usaha kecil masyarakat, khususnya usaha hasil ternak kedua KTT, guna menambah penghasilan mereka, yang pada gilirannya bisa menjadi sarana meningkatkan kesejahteraan dan taraf hidup keluarga para peternak. 


\section{METODE}

Metode yang digunakan dalam Program Kemitraan Masyarakat kepada kedua mitra (kelompok istri peternak sapi perah KTT 'Air Bening I' dan KTT 'Air Bening II') meliputi:

1. Penyuluhan

Metode penyuluhan dilakukan untuk memberikan pengetahuan/penjelasan tentang kandungan gizi susu dan potensi pengolahan susu, teknik pembuatan adonan kerupuk dan stik susu hingga kalis, metode pengirisan adonan kerupuk setelah dikukus, tujuan pengeringan kerupuk basah dan cara kerja mesin pengering, cara kerja alat giling dan cetak stik. Penyuluhan dilakukan oleh Tim pelaksana (dosen) kepada anggota kedua kelompok.

\section{Pelatihan dan praktek}

Pelatihan diberikan dalam bentuk demonstrasi tentang pembuatan kerupuk dan stik susu dilanjutkan dengan praktek oleh para peserta. Pelatihan ini bertujuan agar ibu-ibu peserta mampu membuat olahan makanan dari susu sapi secara mandiri serta mampu menggunakan prasarana peralatan produksi kerupuk dan stik susu yang telah disiapkan Tim PKM. Pembuatan kerupuk susu mengacu pada metode Saputro (2012), sedangkan pembuatan stik susu mengacu pada metode Suwarna (2014). Kedua metode ini menggunakan curd (gumpalan/dadih) susu pada proses pembuatannya. Sebelumnya, Tim PKM telah melakukan uji coba pembuatan kerupuk dan stik susu baik dengan menggunakan susu segar maupun menggunakan curd di laboratorium Teknologi Pangan Politeknik Katolik Mangunwijaya untuk mendapatkan metode terbaik dan komposisi yang tepat tentang pembuatan kerupuk dan stik susu. Kedua produk olahan susu dengan menggunakan curd diperoleh lebih disukai dari segi tekstur, rasa, dan aroma pada uji panelis, dibandingkan yang menggunakan susu segar.

\section{Pendampingan}

Kegiatan berikutnya adalah pendampingan praktek lapangan (praktek produksi makanan olahan susu dan pemasaran produk). Praktek lapangan secara mandiri bertujuan agar mitra mampu menerapkan hasil penyuluhan dan pelatihan tentang pengolahan susu sapi segar menjadi aneka makanan komersial yang telah diikutinya, serta mampu mengemas produk makanan yang dihasilkan secara menarik dan memasarkannya.

\section{Monitoring}

Monitoring kepada mitra pasca penerapan program PKM bertujuan untuk memantau perkembangan kualitas produk, kapasitas produksi, dan penjualan. Dari pelaksanaan monitoring juga untuk mengetahui manfaat dari pelaksanaan program PKM bagi masingmasing mitra.

\section{HASIL DAN PEMBAHASAN \\ Pengolahan susu menjadi kerupuk dan stik susu}

Susu mempunyai manfaat ekonomis yang sangat besar karena selain dapat diminum sebagai susu segar setelah dipasteurisasi, susu juga dapat digunakan sebagai bahan baku produkproduk olahan susu, seperti susu fermentasi (yoghurt, kefir), permen, dodol susu, stik dan kerupuk susu. Pengolahan susu selain untuk menganekaragamkan produk dan selera, juga untuk mengawetkan susu agar relatif lebih tahan lama bila disimpan. Beberapa produk olahan susu ini bahkan memberikan dampak positif dalam kesehatan dan secara ekonomis 
dapat meningkatkan nilai jual susu. Beberapa alternatif produk olahan susu yang dapat dibuat dengan metode dan peralatan yang sederhana, terutama untuk skala rumah tangga, yakni pembuatan kerupuk dan stik susu.

Kerupuk dan stik susu merupakan bahan pangan bersumber protein yang terbuat dari susu, tepung tapioka, dan tepung terigu. Penggunaan bahan baku susu merupakan salah satu alternatif peningkatan nilai gizi. Meskipun kerupuk dan stik susu merupakan bahan pangan ringan, tetapi mengandung protein hewani, yakni digunakannya curd susu.

Curd adalah gumpalan halus berwarna putih pada susu segar yang mendapat perlakuan asam. Curd susu dapat diperoleh dari penambahan enzim bromelin buah nanas atau asam cuka ke dalam susu. Endapan massa yang lunak (curd) kemudian dipisahkan dari cairannya (whey) (Saputro, 2012). Pada proses pengolahan stik dan kerupuk susu terjadi proses gelatinasi pati membentuk gel, yakni perubahan bentuk sistem mobilitas menjadi sistem polimer menggunakan panas dan air. Selain curd dari susu sebagai bahan baku kerupuk dan stik susu, digunakan pula tepung tapioka yang berperan dalam menentukan daya kembang produk. Hal ini dikarenakan kandungan patinya berkisar antara $85-87 \%$ dengan sifat yang mudah membengkak (swelling) dalam panas. Garam dan gula juga ditambahkan untuk memberikan cita rasa pada produk akhir. Bahan ini juga berfungsi sebagai pengawet.

Pada pembuatan stik susu dapat ditambahkan telur dalam adonan karena berfungsi sebagai binding agent yang mampu mengikat bahan-bahan lain. Telur juga berfungsi sebagai emulsifier yang dapat mempertahankan adonan dalam keadaan rata dan menghambat terjadinya pengumpalan untuk mencegah tekstur yang kasar (Setiawati, 2014).

Pada proses pembuatan kerupuk, setelah lontong adonan kerupuk diiris akan dilanjutkan dengan proses pengeringan yang bertujuan untuk meningkatkan daya simpan dan memudahkan penyimpanan kerupuk kering.

Agar proses pengeringan kerupuk susu tidak terpengaruh cuaca dan tetap bisa dilakukan pada saat musim hujan, melalui program PKM ini telah direalisasikan alat pengering/oven untuk mengeringkan irisan kerupuk basah. Alat pengering ini menggunakan pemanas LPG dan dilengkapi dengan exhaust fan agar uap air dari kerupuk basah dapat segera dihembuskan keluar dari dalam alat pengering.

\section{Peserta, Tempat dan Kegiatan PKM}

Peserta Program Kemitraan Masyarakat kali ini adalah kelompok istri peternak sapi perah KTT 'Air Bening I' dan KTT 'Air Bening II' di Kelurahan Wates, Kota Seamarang, Jawa Tengah. Para peserta menyambut baik dan antusias terhadap kegiatan PKM yang dilaksanakan oleh Tim pengabmas Polteka Mangunwijaya. Hal ini ditunjukkan dengan selalu hadirnya mereka dalam setiap kegiatan yang dilakukan.

Tempat kegiatan dilaksanakan di rumah ketua kelompok K'T 'Air Bening I' dan KT'T 'Air Bening II' di RT 03/RW 01, Kelurahan Wates, Kecamatan Ngaliyan, Kota Seamarang. Kegiatan dimulai dengan memberikan penyuluhan, kemudian kegiatan pelatihan dan praktek, pendampingan pada implementasi hasil praktek dan monitoring pasca penerapan program PKM. 
Gambar 1:

Penyuluhan dan pelatihan pembuatan curd susu dan olahannya menjadi kerupuk dan stik susu kepada istri peternak sapi perah KTT 'Air Bening I'
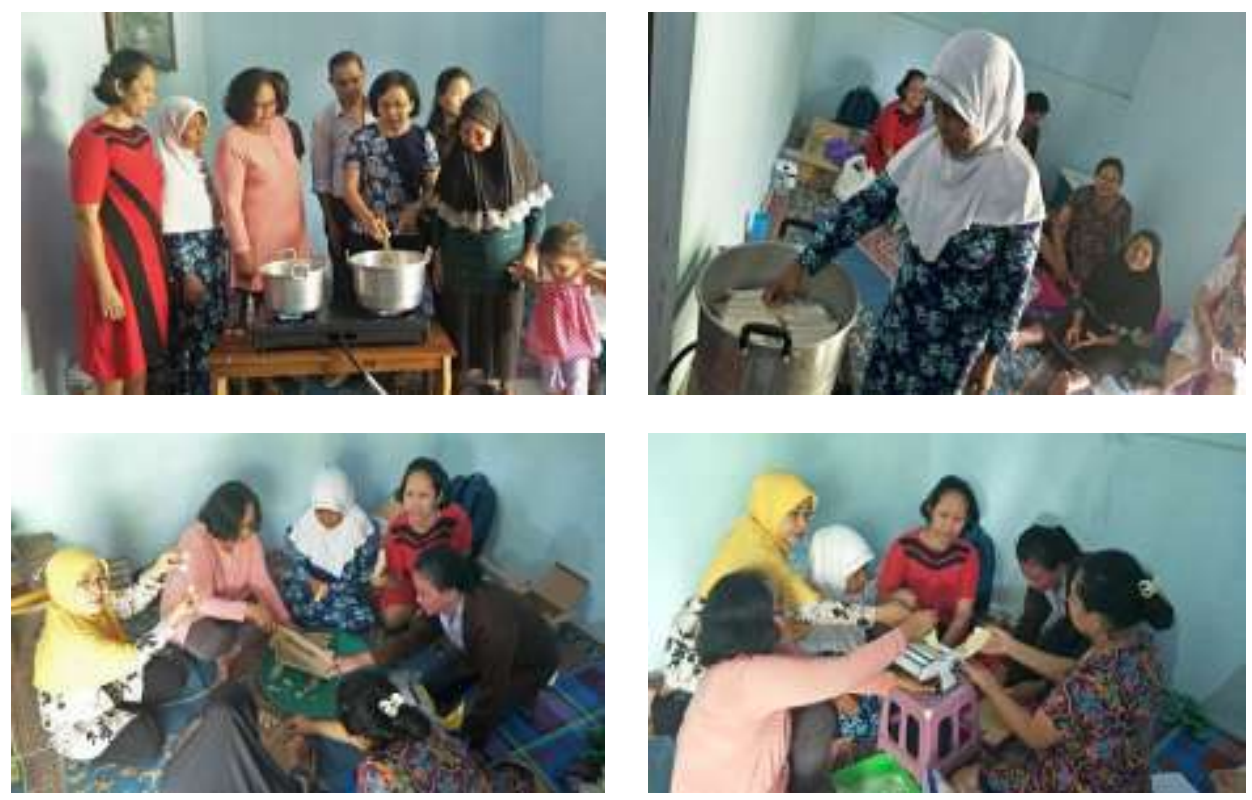

Gambar 2:

Penyuluhan dan pelatihan pembuatan curd susu dan olahannya menjadi kerupuk dan stik susu kepada istri peternak sapi perah KTT 'Air Bening II'
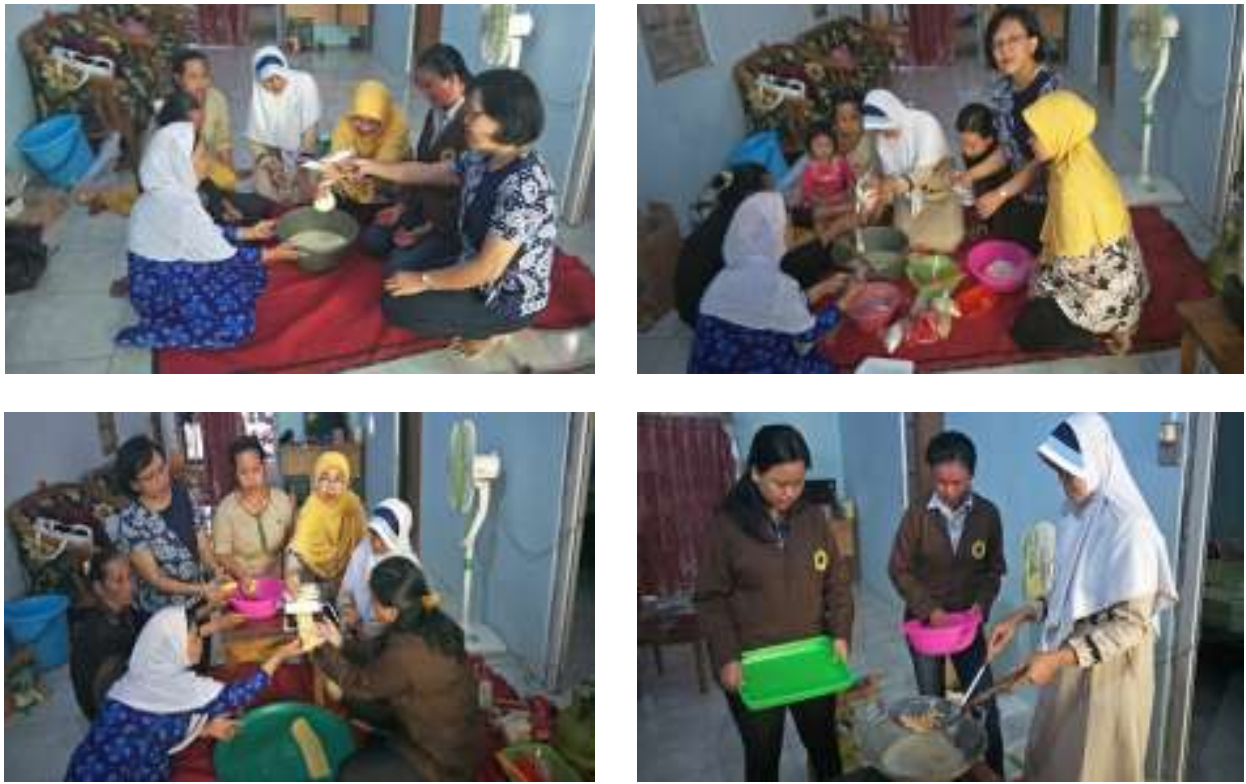
Gambar 3:

Pelatihan teknologi pengeringan kerupuk susu basah kepada kedua mitra
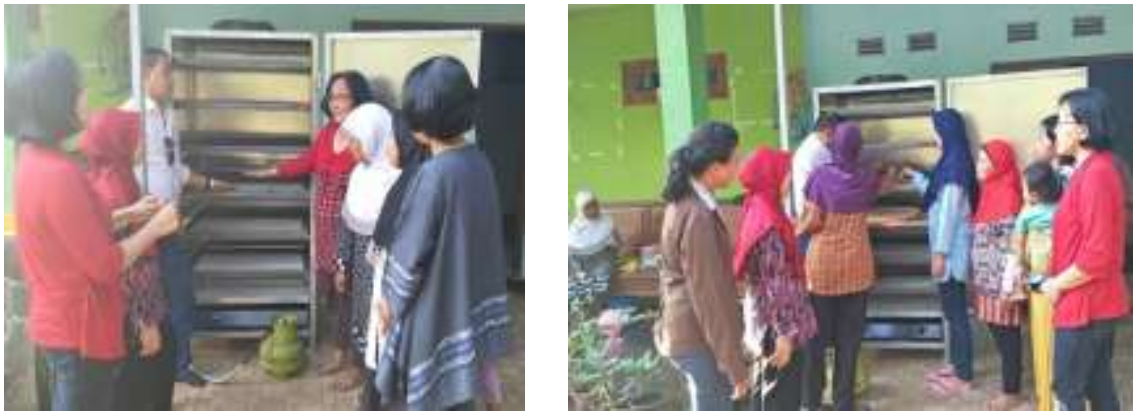

Gambar 4:

Praktek pengemasan produk dan labeling oleh kedua mitra
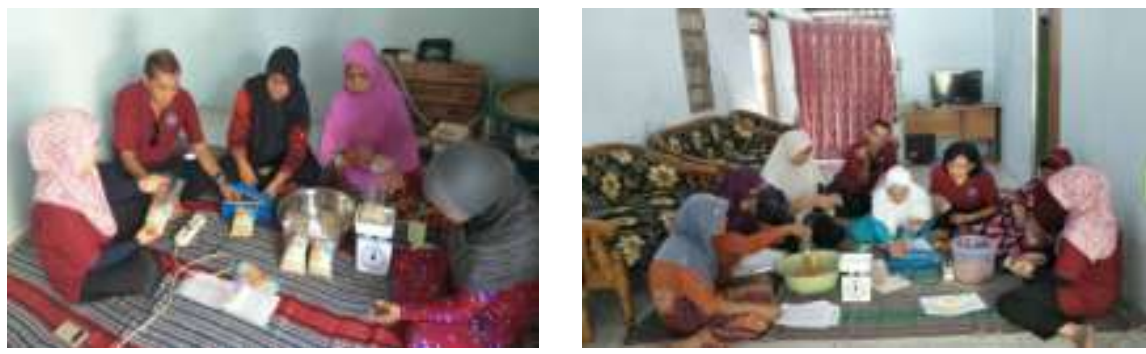

Gambar 5:

Monitoring dan evaluasi pasca penerapan program PKM kepada kedua mitra
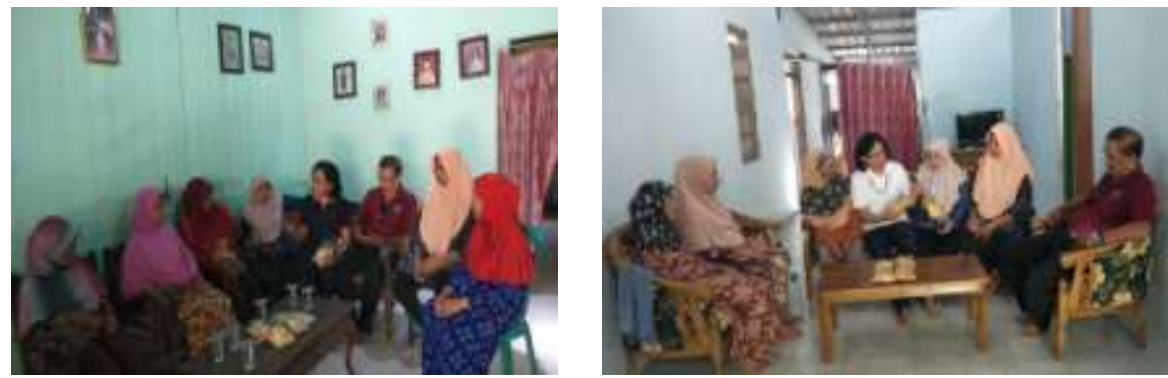

Gambar 6:

Produk hasil kegiatan PKM, (a) kerupuk susu mentah, (b) stik susu, (c) kerupuk susu mentah dalam kemasan, (d) stik susu dalam kemasan

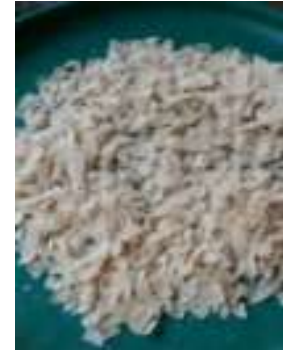

a

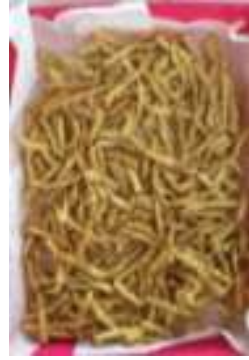

b

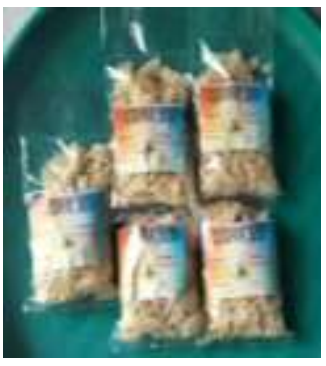

C

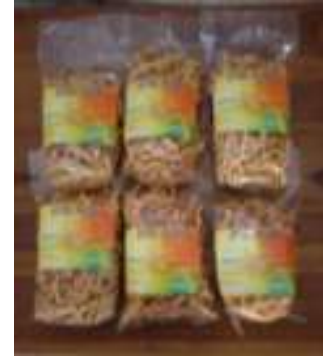

d 


\section{Kendala kegiatan PKM}

Meskipun para anggota kedua mitra memberi respon yang baik selama kegiatan. PKM ini, dari hasil monitoring dan evaluasi masih dijumpai beberapa kendala yang dihadapi, yakni:

1. Tingkat pendidikaan dan keterampilan yang tidak merata dari anggota mitra. Pada umumnya tingkat pendidikaan dan keterampilan ketua mitra lebih baik dibandingkan anggota-anggotanya, sehingga penyerapan iptek tidak merata.

2. Kualitas produk makanan olahan susu yang dihasilkan oleh kedua mitra setelah penerapan PKM masih belum stabil. Pada pembuatan kerupuk dan stik susu, selain rasanya masih berubah-ubah (kadang gurih/enak, empuk, dan renyah, tapi kadang kurang enak dan keras), juga ketebalan serta ukurannya masih belum sama/seragam.

3. Pemasaran produk masih dilakukan di sekitar tempat tinggal dan belum berani ke luar lingkungan karena kualitas produk yang belum stabil terutama dari segi rasa, penampilan, dan tektur produk.

Untuk mengatasi kendala tersebut, upaya yang dilakukan oleh tim PKM adalah selalu memberi motivasi kepada para anggota kedua mitra, serta melakukan pendampingan produksi secara terus dan berkelanjutan kepada mitra untuk menciptakan hasil olahan yang baik dan bermutu.

\section{KESIMPULAN}

1. Pengolahan susu sapi segar untuk bahan baku olahan aneka makanan, selain untuk mengatasi problema susu segar yang tidak laku, juga dapat dijadikan basis membangun usaha untuk menambah pendapatan kedua mitra.

2. Alih Iptek melalui program PKM sangat dibutuhkan oleh kedua mitra untuk meningkatkan keterampilan anggotanya yang dapat dikembangkan sebagai modal merintis usaha kecil untuk sumber penghasilan.

\section{UCAPAN TERIMAKASIH}

Penulis mengucapkan terimakasih kepada DRPM DIKTI selaku Pemberi Dana program PKM, Kelompok istri peternak sapi perah KTT 'Air Bening I' dan KTT 'Air Bening II' selaku Mitra, Direktur serta LPPM Politeknik Katolik Mangunwijaya yang telah menyediakan fasilitas penunjang, dan mahasiswa: Maria Shinta Crisyanti dan Fionda Oseana Alocita yang telah membantu pelaksanaan PKM.

\section{DAFTAR PUSTAKA}

Saleh, E. (2004). Teknologi pengolahan susu dan hasil ikutan ternak. Medan (ID): Program Studi Produksi Ternak Fakultas Pertanian Universitas Sumatera Utara.

Saputra, E. (2012). Membuat Kerupuk Susu. Bahan Ajar Diklat Teknis Pengolahan Hasil Ternak. Badan Penyuluhan dan Pengembangan SDM Pertanian Balai Besar Pelatihan Peternakan Batu.

Setiawati, N. R. (2014). Stik Susu. Laboratorium Teknologi Pengolahan Pangan, Jurusan Tek. Pangan. Bandung: Fakultas Teknik, Universitas Pasundan.

Suwarna. (2014). .Membuat Stik. Susu. Sumber:

http://cybex.pertanian.go.id/mater ipenyuluhan/detail/9175/membuat -stik-susu. Diakses 11 Juni 2017 